\title{
A Comparative Analysis of Contribution of Human Resource Management to Organizational Performance of Banks in Serbia
}

\author{
Article history \\ Received: 16 September 2013 \\ Sent for revision: 21 October 2013 \\ Received in revised form: 22 November 2013 \\ Accepted: 23 November 2013 \\ Available online: 26 November 2013
}

\begin{abstract}
The contribution of this paper is in identification, proving and presentation of practice quality of human resource management as an important factor for achieving organizational effectiveness of banks. A group of correlations has been defined in this paper to be measured in order to reflect the impact of HRM practice on the effectiveness of banks in Serbia, which can lead to better functioning of not only banking organizations, but also of all other organizations in our environment and under current circumstances. The results of this study showed that banking organizations that have better HRM practices possess a more competitive workforce and better organizational performances, which further highlight the need for a more systematized and institutionalized use of human resources within commercial banking sector in Serbia.
\end{abstract}

Keywords: human resources, human resources management, employee satisfaction, organizational performance

\footnotetext{
${ }^{1}$ University Educons, Faculty of Business in Service, Sremska Kamenica, djurkovic.jelena@yahoo.com

${ }^{2}$ University Educons, Faculty of Business Economy, Sremska Kamenica, jelenajotic@gmail.com

${ }^{3}$ University Educons, Faculty of Business Economy, Sremska Kamenica, radenko.maric@yahoo.com
} 
Vemić Đurković J. et at.: A Comparative Analysis of Contribution of Human Resource...

\title{
Uporedna analiza doprinosa upravljanja ljudskim resursima organizacionim performansama banaka u Srbiji
}

\begin{abstract}
Apstrakt: Doprinos ovog rada je u prepoznavanju, dokazivanju i prezentaciji kvaliteta prakse menadžmenta ljudskih resursa kao važnog faktora za postizanje organizacione uspešnosti banaka. U okviru ovog rada definisana je grupa odnosa koje treba meriti kako bi se refelektovao uticaj prakse menadžmenta ljudskih resursa na uspešnost banaka u Srbiji što može poslužiti boljem funkcionisanju ne samo bankarskim organizacijama, već $i$ svim drugim organizacijama u našim uslovima i u postojećoj situaciji. Rezultati istraživanja pokazali su da one bankarske organizacije koje imaju kvalitetnije prakse menadžmenta ljudskih resursa imaju konkurentniju radnu snagu i bolje organizacione performanse što dalje ukazuje na potrebu za sistematizovanijem $i$ institucionalizovanijem korišćenjem ljudskih resursa u sektoru poslovnog bankarstva u Srbiji.
\end{abstract}

Ključne reči: ljudski resursi, menadžment ljudskih resursa, zadovoljstvo zaposlenih, organizacione performance

\section{Introduction}

Reform of the banking sector in Serbia, followed by changes in the ownership, organizational, financial and management structures that led to a more efficient and profitable operations of banks, their inclusion in the modern capital flows, creation of new banking products and provision of better services to clients, attached the importance to human resources. The reason for this lies in the fact that effectiveness of banking sector's transformation processes implied radical changes in workforce, which further required proper management where adequate management of employees played a significant role. This caused different (than of personnel management) treatment and evaluation of human resource management practice (finding its strategic importance) and recognition that a bank through its management of employees can develop a specific set of competencies that distinguishes it from other banks, and thus achieve differentiation in a competitive banking market, which is of great importance since the banking services do not differ much from each other and that the manner of their distribution to clients is far more important for effectiveness. 
Vemić Đurković J. et at.: A Comparative Analysis of Contribution of Human Resource...

The fact that the processes of privatization and restructuring, mergers and acquisitions of banks did not take into account people resources of those organizations in any form, that no bank represented the item of people resources in its balance sheets, that few banking organizations have business position called "Human Resources Management", but do not have a position "Measurement of human resources", indicates the need for a more systematized use of human resources in the banking sector. For many managers and their organizations, people and human resources department are more important in their opening lines of written documents and speeches than in reality. Many managers still believe that human resources department is a cost centre with a goal to minimize expenditures and an indicator of effectiveness, and that it rarely adds value to organizations, i.e. contributes to the achievement of profit, which also explains why it is difficult to obtain the necessary resources to these departments for their work. The main reason for the above is that the impact of human resource management on bank's performance is not easy to be measured. In order to justify necessary investments, it is required to demonstrate contribution of human resource management practice to the organizational effectiveness of banks.

The main purpose of this study is to form a complex model of correlations between HRM practice and organizational performance of banks, which can serve as a basis for possible study, not only to which extent but also how these practices generate business effectiveness. Insufficient level of knowledge on correlations between human resource management practice and organizational performance reduces the ability not only of banks but also of all other companies in the economic system of Serbia, to adequately manage their most valuable asset - human resources. Accordingly, this study is the first step towards finding a way that will enable not only banks but also other types of organizations in Serbia to better use and develop human resources, thus increasing their competitiveness and ensuring the future prosperity being of great importance given the difficult business conditions arising from the impact of the global economic crisis faced by our companies. 
Vemić Đurković J. et at.: A Comparative Analysis of Contribution of Human Resource...

\section{Theoretical Studies on Measuring the Impact of Human Resource Management on Effectiveness}

The role of human resources management in achieving effectiveness can be perceived, on one hand, in the fact that employees have the ability to create values, and being, on the other hand, the source of bank's costs. The issue is the complexity of what is measured - human resources are a key business asset, but much more complex than any other. One of the main attributes of human resources is their property - knowledge, intangibility, latency which makes it difficult to determine their economic value. There are several factors that hinder the measurement of contribution of human resource management to organization's effectiveness: indirect nature of value realized by applying this practice, it indirectly generates financial results, i.e. through chains of causal relationships including two or more links. Value is contextual, i.e. it depends on a specific organizational strategy and goals. Idiosyncratic nature of human resource management practice, implying what is valuable and useful for one bank may be worthless and useless for the other one, results in different measurement systems. The value of human resources management is a potential, and investment in its quality has a potential value but not a market value. The market value is achieved only by including employees' competences in the services, but measured through the quality of banking services. It is paradoxical that although organizations accepted the importance of human resources, corporate investments in human resources such as basic skills, qualitative training or funding of further education, are rarely measured and little is known how much benefit is obtained by such investments. It is common for accounting and finances within an organization to closely track and analyze all types of investment in physical capital, research and development, while investment in human resources is rarely found in accounting reports (Zubović, Jeločnik, Subić, 2011). The very fact that knowledge, as a key economic resource in modern business, is a human product and that it may be accessed and used through people, for creating an additional value, speaks for itself about the connections that are undisputed and should not be proved. The analysis in this paper is focused primarily on explaining how these influences are realized and how management processes should be set up to generate value-gaining knowledge.

Having reviewed the relevant literature on this subject, three large groups of studies can be distinguished on correlation between practice of human re- 
Vemić Đurković J. et at.: A Comparative Analysis of Contribution of Human Resource...

source management and organizational performance: first, the study on impact of certain activities of human resource management on organizational performance, such as: training and development (Delaney \& Huselid, 1996; Russell, Terborg \& Powers, 1985 Bartel, 1994; Knoke \& Kalleberg, 1994), recruitment and selection (Terpstra and Rozell,1993; Delaney \& Huselid, 1996; Nicholas, 2005), tracking work effectiveness (Borman, 1991), compensation and rewarding (Snell, 1992; Koch \& McGrath, 1996; Delaney \& Huselid, 1996; Ehrenberg and Milkovitch, 1988); creating appropriate organizational culture and climate (Cutcher-Gershenfeld, 1991; Wagner, 1994, Appleyard \& Brown, 2001); second, study on the impact of human resource management activities on organizational performances (Kravetz, 1988; Phillips, 1988; Albert, 1990; Wright and McMahan 1992; Arthur, 1994; Huslid, 1994 and 1995; MacDuffie, 1995; Becker \& Gerhart, 1996; Welbourne \& Andrews, 1996; Huselid \& Becker, 1996 and 1997; Jalette, 1997; Ichniowski, Shaw \& Prennushi, 1997; Guthrie, 1999; Bea \& Lawler, 2000; Batt, 2000), and third, studies indicating that, apart from the basic groups of human resource management activities, the effectiveness of organizations is linked to some general indicators related to employees and human resources management, such as organizational units for human resource management (Ferris, Russ, Albanese \& Martocchio, 1990), job security (Delery \& Doty, 1996; Shaw, Delery, Jenkins \& Gupta, 1998), job satisfaction and loyalty to an organization (Patterson, West, Lawthom \& Nickell, 1997), knowledge creation (Collins, Smith \& Stevens, 2001), capabilities of HR managers (Huselid, Jackson \& Schuler, 1997), quality program initiatives related to HRM (Monks, Buckley \& Sinnot, 1996).

Having reviewed these studies, it can be said that quality procedures of HRM practices may, but need not result in good organizational performances, although it is quite possible to assume that organization's performance can be enhanced by applying high quality procedures of such practice. Therefore, the comparative analysis in this paper on the contribution of HRM practices to operating effectiveness of banks required the introduction of mediating variables. The following two mediating variables are chosen: the value (quality) of human resources and drivers of human resources. A theoretical basis for introducing these mediating variables was found within the theory of enterprises based on resources, and behavioural theory. According to these theoretical sources, an organization creates its programs of human resources management in line with its needs in order to produce certain knowledge (employees competences), as well as behavior and attitudes of employees 
Vemić Đurković J. et at.: A Comparative Analysis of Contribution of Human Resource...

(Lawler,1986; Huselid, 1995; Becker, Huselid, Pickus \& Spratt, 1997; Guest, 1997; Appelbaum et al., 2000; Takeuchi, 2003). Dealing with increasingly fierce competition and harsh conditions of doing business in an increasingly unstable environment, organizations adopt different approaches to motivation, measure and improve employee satisfaction, build a strong organizational culture and strengthen communication system, in order to create certain attitudes, values, behaviour and actions of employees in accordance with the organizational goals and needs. Therefore, the study of these factors is important, as they are increasingly becoming critical for achieving business effectiveness. Without diminishing the value and importance of any of these factors, and due to objective inability to analyze the effect of each factor, and in order to satisfy the basic needs of this research, the analysis covered only one factor - employee job satisfaction (hereinafter named as driver of human resources).

\section{Scope, Goals, Hypotheses and Methodology of Research}

The research focuses on producing argumentation and proof of hypothetical connection between the quality of human resource management practice and business effectiveness of banks on such basis. The main goal of this research is to indicate that differences in the quality of human resource management practices cause the differences in organizational performances, but primarily cause the differences in quality of human resources and quality of human resources drivers. In that respect, the main purpose of the research was to test the generally accepted theory on the contribution of HRM practices to organizations effectiveness, via several types of relationships (links) that serve as the basis for an integrative model of the contribution of HRM to organizations effectiveness within commercial banking sector in Serbia and enable better insight into not only to which extent, but also how HRM practices generate their business effectiveness. The main hypothesis of this study is:

Ho: A quality practice of human resource management contributes to better organizational performances within commercial banking sector in Serbia.

Defined scope, objectives and hypothesis of the study have caused the creation of four research fields: organizational performance, quality of current practices of human resource management, quality of human resources and quality of human resources drivers (employee job satisfaction) in the surveyed 
Vemić Đurković J. et at.: A Comparative Analysis of Contribution of Human Resource...

banks. Questionnaire was used as a surveying method in the analysis. As an instrument of the research, the questionnaire used contained a total of 89 questions which covered indicators defined for each research field.

The initial idea of this study was to find a way to analyze, at a multidimensional level, the contribution of human resource management practice to operating effectiveness of the surveyed banks. For such purpose, this study used percentiles and percentile ranks. Scale score was calculated for defined indicators for each research field and it represents the result of each respondent (case) on factor, obtained by adding the results. On such basis the evaluation of banks was performed, while the end result of the analysis was its multicriteria ranking for each research field. Multi-criteria ranking of banks was presented for more simplified way of drawing the conclusions on whether and to what extent they are correlated, based on the use of percentiles and percentile ranks, in three groups: above average banks, average banks, and below average banks. This enables not only the observation of several indicators simultaneously but also an appreciation of the fact that different indicators have different effect on specific goal, through allocation of rank (values, weights). This allowed for a better understanding of not only to which extent, but also how the practice of human resource management generates business effectiveness. Statistical analysis of the results obtained by empirical research was carried out in accordance with most appropriate and accepted mathematical and statistical methods. This paper used descriptive, correlation and factor analysis.

The research sample consists of twelve banks. The representativeness of the sample can be argued by the following data: assets of surveyed banks account for $41 \%$ of total assets of the commercial banking sector; capital of surveyed banks is $41 \%$ of total capital of commercial banking sector, pre-tax profit of surveyed banks amounts to $37 \%$ of total profit of commercial banking sector, number of employees in surveyed banks makes $42 \%$ of total number of employees in commercial banking sector. 
Vemić Đurković J. et at.: A Comparative Analysis of Contribution of Human Resource...

\section{Presentation and Interpretation of Obtained Study Results}

\subsection{Analysis of Organizational Performance of Surveyed Banks}

Table 1. Multi-criteria ranking of surveyed banks by: financial performances (Column 1 \& 2); non-financial performances (Column 3 \& 4); quality of HR practices (Column $5 \& 6$ ); quality of human resources (Column $7 \& 8$ ) and employees' satisfaction with their job (Column $9 \& 10)$

\begin{tabular}{|c|c|c|c|c|c|c|c|c|c|c|c|}
\hline \multirow{2}{*}{ No. } & \multirow{2}{*}{ Bank name } & Value & Rank & Value & Rank & Value & Rank & Value & Rank & Value & Rank \\
\hline & & 1 & 2 & 3 & 4 & 5 & 6 & 7 & 8 & 9 & 10 \\
\hline 1 & $\begin{array}{l}\text { Banca } \\
\text { Intesa }\end{array}$ & 1.96 & 1 & 20.00 & 1 & 128,00 & 3 & 44.00 & 1 & 41.00 & 1 \\
\hline 2 & $\begin{array}{l}\text { Komercijalna } \\
\text { banka }\end{array}$ & 1.56 & 2 & 19.00 & 2 & 119,00 & 4 & 42.00 & 2 & 36.00 & 4 \\
\hline 3 & VolksBank & -.03 & 6 & 9.00 & 8 & 106,00 & 6 & 38.00 & 5 & 35.00 & 5 \\
\hline 4 & Agrobanka & .25 & 5 & 12.00 & 5 & 102,00 & 7 & 32.00 & 6 & 32.00 & 7 \\
\hline 5 & ErsteBank & .28 & 4 & 14.00 & 4 & 131,00 & 2 & 40.00 & 3 & 40.00 & 2 \\
\hline 6 & $\begin{array}{l}\text { Credit } \\
\text { Agricole } \\
\text { Banka }\end{array}$ & -.46 & 8 & 11.00 & 6 & 57,00 & 11 & 21.00 & 9 & 19.00 & 10 \\
\hline 7 & OTP Banka & -1.20 & 12 & 10.00 & 7 & 55,00 & 12 & 25.00 & 8 & 20.00 & 9 \\
\hline 8 & KBC Banka & -.53 & 9 & 7.00 & 10 & 67,00 & 10 & 25.00 & 8 & 19.00 & 10 \\
\hline 9 & $\begin{array}{l}\text { Čačanska } \\
\text { banka }\end{array}$ & -.24 & 7 & 8.00 & 9 & 111,00 & 5 & 32.00 & 6 & 33.00 & 6 \\
\hline 10 & $\begin{array}{l}\text { Findomestic } \\
\text { banka }\end{array}$ & -1.17 & 11 & 6.00 & 11 & 79,00 & 9 & 26.00 & 7 & 30.00 & 8 \\
\hline 11 & $\begin{array}{l}\text { Hypo Alpe } \\
\text { Adria banka }\end{array}$ & .53 & 3 & 15.00 & 3 & 132,00 & 1 & 39.00 & 4 & 37.00 & 3 \\
\hline 12 & $\begin{array}{l}\text { Opportunity } \\
\text { banka }\end{array}$ & -.96 & 10 & 5.00 & 12 & 97,00 & 8 & 32.00 & 6 & 35.00 & 5 \\
\hline
\end{tabular}

Source:Author

The analysis of organizational performance of surveyed banks considered financial indicators: changes in assets, market share, ROA, and ROE. Having reviewed different financial parameters simultaneously and calculated their scale scores, Table 1 provides a multi-criteria ranking of the surveyed banks according to financial performances (Column $1 \& 2$ ). Based on the use of percentiles and percentile ranks shown in Table 2, surveyed banks are ranked according to financial performances (Column 1). 
Vemić Đurković J. et at.: A Comparative Analysis of Contribution of Human Resource...

Table 2. Percentiles for defining the rank of surveyed banks by: financial performances (Column 1); non-financial performances (Column 2); quality of HR practices (Column 3); quality of human resources (Column 4) and employees' satisfaction with their job (Column 5).

\begin{tabular}{|c|c|c|c|c|c|c|c|c|c|c|}
\hline & & 1 & \multicolumn{2}{|c|}{2} & \multicolumn{2}{|r|}{3} & \multicolumn{2}{|r|}{4} & \multicolumn{2}{|r|}{5} \\
\hline Mean & \multicolumn{2}{|c|}{.0000} & \multicolumn{2}{|c|}{.0000} & \multicolumn{2}{|c|}{33.0000} & \multicolumn{2}{|c|}{33.0000} & \multicolumn{2}{|c|}{31.4167} \\
\hline Std. Deviation & \multicolumn{2}{|c|}{1.00000} & \multicolumn{2}{|c|}{1.00000} & \multicolumn{2}{|c|}{32.0000} & \multicolumn{2}{|c|}{32.0000} & \multicolumn{2}{|c|}{34.0000} \\
\hline Median & \multicolumn{2}{|c|}{-.1337} & \multicolumn{2}{|c|}{10} & \multicolumn{2}{|c|}{7.60383} & \multicolumn{2}{|c|}{7.60383} & \multicolumn{2}{|c|}{7.90234} \\
\hline Minimum & \multicolumn{2}{|c|}{-1.20} & \multicolumn{2}{|c|}{5.00} & \multicolumn{2}{|c|}{55.00} & \multicolumn{2}{|c|}{21.00} & \multicolumn{2}{|c|}{19.00} \\
\hline Maximum & \multicolumn{2}{|c|}{1.96} & \multicolumn{2}{|c|}{20.00} & \multicolumn{2}{|c|}{132.00} & \multicolumn{2}{|c|}{44.00} & \multicolumn{2}{|c|}{41.00} \\
\hline \multirow[t]{2}{*}{ Percentiles } & 33 & -.5080 & 33 & -8.5 & 33 & 50.7400 & 33 & 27.7400 & 33 & 30.5800 \\
\hline & 67 & .2710 & 67 & 13 & 67 & 112.7100 & 67 & 38.7100 & 67 & 35.7100 \\
\hline
\end{tabular}

Source:Author

Evaluation and ranking of surveyed banks per financial performances were performed on the basis of applied percentiles and percentile ranks, in three groups: above average banks (value - above C67 centiles): Banka Intesa, Komercijalna, Hypo and Erste banka, average banks (value between C34 and C66 centiles): Agrobanka, Volks, Čačanska and Credit Agricole banka, and below average banks (value - below C33 centiles): KBC, Opportunity, Findomestic and OTP banka.

The analysis of organizational performances of surveyed banks used nonfinancial indicators, such as the number of clients, outposts, branches and ATMs. The starting point was that banks that have a larger number of clients, outposts, branches and ATMs as an indicator of increased availability of banking services to clients and thus better services, are more effective than those that do not. Sampled banks, which present better performances according to these indicators, are as follows: Banka Intesa, Komercijalna banka, Hypo, Erste, Agricole, and Agro banka. The analysis of non-financial performances took into account the quality of banking services and clients satisfaction with provided banking services. Two questions from the questionnaire served as good indicators for inferring conclusions on operating effectiveness of surveyed banks according to quality of service and clients satisfaction on provided banking services: (not)having certificates, prizes or awards for quality of banking services, and (ir)regular tracking of clients satisfaction. The starting point was that the banks which received recognition for the quality of their services (Banka Intesa, Komercijalna, Agrobanka, Erste, Hypo, OTP, and 
Vemić Đurković J. et at.: A Comparative Analysis of Contribution of Human Resource...

Volks banka) and which regularly track their clients satisfaction (Banka Intesa, Komercijalna, Erste, Hypo banka) are more effective than banks that do not have it or do not have such practices. The evaluation and ranking of surveyed banks per non-financial indicators was carried out by using the same procedure as in financial indicators. Table 1 (Column $3 \& 4$ ) illustrates a multicriteria ranking of surveyed banks by non-financial performances. Ranks of surveyed banks by non-financial performances are then defined based on used percentiles and percentile ranks shown in Table 2 (Column 2).

Evaluation and ranking of surveyed banks per non-financial performances were performed on the basis of applied percentiles and percentile ranks, in three groups: above average banks (value - above C67 centiles): Banka Intesa, Komercijalna, Hypo, and Erste banka, average banks (value between C34 and C66 centiles): (Agrobanka, Credit Agricole, OTP and Volks banka, and below average banks (value - below C33 centiles): Čačanska, KBC, Findomestic, and Opportunity banka.

Combining of data provides a final multi-criteria ranking and classification of surveyed banks by organizational performances: Banka Intesa, Komercijalna, Hypo and Erste banka (group of above average banks), Agrobanka, Volks, Credit Agricole and Čačanska banka (group of average banks), and KBC, OTP, Findomestic and Opportunity banka (group of below average banks). The analysis of presented multi-criteria rankings indicates there are no significantly major deviations, which means the banks that have a greater number of clients, branches, employ more workers, have some kind of recognition for the quality of their banking services and in a way track clients satisfaction with provided banking services, achieve better financial results.

\subsection{Analysis of Practice Quality of HRM in Surveyed Banks}

Quality of current practices of human resource management in surveyed banks was analyzed in the study based on four groups of indicators: competitiveness of employees in bank's HR departments (value, quality of employees in HR department), quality of HR department work organization, quality of performing generic HR activities and evaluating the importance of HR practices. Observing at the same time different parameters within these four groups of indicators and calculating their scale scores, Table 1 (Column $5 \& 6$ ) illustrates a unique multi-criteria ranking of banks by quality of current HR practic- 
Vemić Đurković J. et at.: A Comparative Analysis of Contribution of Human Resource...

es. Ranks of surveyed banks by quality of current HR practices are defined based on used percentiles and percentile ranks shown in Table 2 (Column 3).

Evaluation and ranking of surveyed banks by quality of human resources management practices were performed on the basis of applied percentiles and percentile ranks, in three groups: above average banks (value above C67 centiles): Hypo, Erste, Intesa and Komercijalna banka, average banks (value between C34 and C66 centiles): Čačanska, Volks, Agrobanka and Opportunity banka, and below average banks (value below C33 centiles): Findomestic, KBC, Credit Agricole and OTP banka.

For a comprehensive analysis of current HR practices quality in surveyed banks, it is not enough to simply state, or evaluate and rank banking organizations on such basis, because it does not provide an answer to the meaning of difference in quality of human resource management practices based on which their assessment and ranking were performed. The answer was provided in the study through descriptive analysis of current HR practices in surveyed banks. Descriptive analysis clearly pointed out the difference between three groups of surveyed banks for all four groups of indicators.

The banks that apply a more developed practice of human resource management, have: more competitive employees in HR departments (younger, more skilled experts); better organization of their work (departments are divided into sectors, outsourcing of certain HR activities, as well as clear, defined and adopted procedures for performing HR processes); better approach to performance of main HR activities: plans of needs for human resources are regularly made, a strategic approach to $\mathrm{HR}$ activities, a succession plan for key people in the organization, profile of demands for working positions is precisely defined, not only in terms of vocational education, but also in terms of knowledge, abilities, skills, experience, personal qualities and physical (fitness) requirements, the existence of a wide and developed range of methods of recruitment, selection, evaluation, training and career development of staff, clear criteria for evaluating job performance, discussion with employees about their achieved work results for establishing corrective measures, using apart from salary other forms of stimulation, there are developed programs focused on health and safety of employees; greater integration of HR activities: information from profile of demands for working positions used to make decisions about the selection, training, career advancements, evaluation of employees work, as well as reward systems, training results are monitored not only from the aspect of cost, but also in terms of performance and improvement of busi- 
Vemić Đurković J. et at.: A Comparative Analysis of Contribution of Human Resource...

ness, promotion to higher positions is based on careful tracking and identification of achieved operating results, etc.; a strategic approach to HR activities: HR department has a manager who actively participates in the work of the bank's Board of Directors which confirms the fact they strategically treat HR activities, recognize the importance of HR activities to improve the quality of banking services and employee satisfaction, more appropriate names of their departments; more financial investments in HR activities: (investment in additional staff training in HR department, hiring new employees in the department, investment in quality of HR activities); developed and formalized evaluation system of the HR department results, which implies there are several participants assessing and evaluating the performance, not only from the aspect of cost but also from the point of effects and satisfaction of clients.

\subsection{Analysis of Human Resources Quality in Surveyed Banks}

Multi-criteria ranking of banks surveyed by quality (value, competitiveness) of human resources was carried out in the same manner as for previous research field (quality of human resource management practice). Observing at the same time different parameters within the indicators of human resources values and calculating their scale scores, Table 1 (Column 7 \& 8) illustrates a multi-criteria ranking of surveyed banks by quality of human resources. Ranks of surveyed banks by quality of human resources are defined based on used percentiles and percentile ranks shown in Table 2 (Column 4).

Evaluation and ranking of surveyed banks by quality of human resources were performed on the basis of applied percentiles and percentile ranks, in three groups: above average banks (value above C67 centiles): Banka Intesa, Komercijalna, Erste and Hypo banka, average banks (value between C34 and C66 centiles): Volks, Agrobanka, Čačanska and Opportunity banka, and below average banks (value below C33 centiles): Findomestic, OTP, KBC, and Credit Agricole banka.

Descriptive analysis of human resources quality of surveyed banks covered the following indicators: demographic characteristics of employees (average age, sex distribution), indicators of education (competence) of employees (average qualification structure of employees, investment in their education, qualification structure of the newly-employed), and indicators of transfer of employees (employee's average length of service). 
Vemić Đurković J. et at.: A Comparative Analysis of Contribution of Human Resource...

Descriptive analysis clearly pointed out the difference in quality of human resources between the three groups of surveyed banks. The banks that have more competitive employees also have the following characteristics: employ younger workers, more proportional sex distribution, workforce is frequently transferred, lower turnover rate, fewer sick days per employee per annum, and they employ new people, have more qualified staff and more time and financial resources to invest in additional staff training unlike those banks that record a lower value of human capital.

\subsection{Analysis of Quality of HR Drivers in Surveyed Banks}

Multi-criteria ranking of banks surveyed by employees' satisfaction with their job was carried out in the same manner as for previous research fields. Observing at the same time different parameters within the indicators of employee satisfaction with job and calculating their scale scores, Table 1 (Column 9 \& 10) illustrates a multi-criteria ranking of surveyed banks by quality of this driver of human resources. Ranks of surveyed banks by quality of this driver of human resources are defined based on used percentiles and percentile ranks shown in Table 2 (Column 5).

Evaluation and ranking of surveyed banks by quality of this driver of human resources were performed on the basis of applied percentiles and percentile ranks, in three groups: above average banks (value above C67 centiles): Intesa, Erste, Hypo and Komercijalna banka, average banks (value between C34 and C66 centiles): Volks, Opportunity, Čačanska and Agrobanka, and below average banks (value below C33 centiles): Findomestic, OTP, Credit Agricole and KBC banka.

Differences in employee satisfaction with job were observed in the study through descriptive analysis based on three groups of indicators: job-related indicators, indicators related to interpersonal relationships and communication, and employees' attitude towards the bank. The banks that have better human capital drivers, regularly conduct surveys of employee satisfaction, ratio between sources of satisfaction and dissatisfaction is in favour of satisfaction and of all three sets of indicators: job, interpersonal relations and communication, and employees' attitude towards the bank, also show better results indicating that their employees are more satisfied. 
Vemić Đurković J. et at.: A Comparative Analysis of Contribution of Human Resource...

\section{Testing the Hypothesis Proposed by the Study: Factor and Correlation Analysis}

Results of the analysis of sampled surveyed banks that have been presented in the paper (evaluation and ranking of banks by calculating scale scores and using percentiles and percentile ranks, as well as descriptive analysis) provided specific answers to two questions: first, which banks are more superior according to four defined groups of indicators, and second, what and which differences exist between them according to described characteristics of those indicators. Presented results of the analysis did not fully proved the hypothesis proposed in the study, i.e. they did not show how much the indicators used in the descriptive analysis are relevant for operating results (tried to be answered by factor analysis), and whether there are connection between them and to which extent (tried to be answered by correlation analysis).

Factor analysis of the main components (main factors describe $61.78 \%$ of the total variance for the observed set of indicators of HR practices quality, $65.83 \%$ of the total variance for the observed set of indicators of human resources quality, and $67.25 \%$ of the total variance for the observed set of indicators of HR drivers quality), indicated that questionnaire is suitable for studying HRM practices quality, quality of HR and HR drivers of banking organizations, i.e. that the questions in the questionnaire can satisfactorily explain the differences in their dominant characteristics. The method of main components extracted (reduced) more significant factors (from the aspect of contribution to organizational effectiveness) that are most relevant in statistical terms for describing differences in the dominant characteristics particularly for each research field. Factor analysis provided an overview of key factors and their values, as well as their manifestation variables (variables that have the highest factor coordinates, i.e. contribute the most to the relevant factor). Reduction of indicators belonging to the set of HRM practices highlighted the following indicators relevant to organizational performance of surveyed banks: quality of the HR department work organization (.921), integration of HR activities (.989), HR strategic importance (.988), practices and investments in HR practices (.985). Among generic HR activities, job effectiveness evaluation and reward system have the highest value. Reduction of indicators that belong to the set of human resources competitiveness pointed out the following indicators relevant to organizational performance of surveyed banks: investment in further education (.967). Reduction of indicators that belong to the set 
Vemić Đurković J. et at.: A Comparative Analysis of Contribution of Human Resource...

of human resources drivers' quality highlighted the following indicators relevant to organizational performance of surveyed banks: survey of employees' satisfaction (.943), employees' attitude towards the bank (.945). In this way, factor analysis complemented descriptive analysis describing these factors, but failed to answer the question about their importance. Pearson's correlation of presence of the most important factors in surveyed banking organizations analyzed the connection between the quality of human resource management practice and organizational performance of surveyed banks.

The results of Pearson's correlation show that correlations between all indicators are important, confirming that the hypotheses proposed in the study are proven. Evidence that the quality of human resource management practice has a positive impact on organizational performance of surveyed banks was provided by the following correlations: HR practice quality and organizational performance: $r=749$, $p \leq 0,01$ - high correlation, HR practice quality and HR quality: $r=, 917 \quad p \leq 0,01$ - high correlation, HR quality and organizational performance: $r=, 704, p \leq 0,01$ - high correlation, HR practice quality and HR drivers quality: $r=, 917 p \leq 0,01$ - high correlation, HR drivers quality and organizational performance: $r=, 865 p \leq 0,01$ - high correlation, and high correlation between the human resources drivers quality and human resources value: $r=$ ,892 $\mathrm{p} \leq 0,01$.

Spearman's correlation coefficient was used in this study for testing proposed hypotheses. Spearman's correlation of multi-criteria ranks of banks, presented in the paper's descriptive analysis, confirmed a high correlation between HRM practices quality and organizational performances in surveyed banks: HR practices quality and organizational performances: Spearman's $\rho=.769$, $p \leq 0,01$; HR practices quality and HR quality: Spearman's $\rho=.868, p \leq 0,01 ; H R$ practices quality and HR drivers quality: Spearman's $\rho=.765, p \leq 0,01$; HR quality and organizational performances: Spearman's $\rho=.808, p \leq 0,01 ; \mathrm{HR}$ drivers quality and organizational performances: Spearman's $\rho=.749, p=0,01$; HR drivers quality and HR quality: Spearman's $\rho=.802, p \leq 0,01$

\section{Conclusion}

This study appeared as a response to the current transitional events faced by entire Serbian society and economy. Reform of the banking sector in Serbia in current transition period, followed by changes in the ownership, organization- 
Vemić Đurković J. et at.: A Comparative Analysis of Contribution of Human Resource...

al, financial and management structures that led to a more efficient and profitable operations of banks, their inclusion in the modern capital flows, creation of new banking products and provision of better services for clients, attached the importance to human resources management. The reason for this lies in the fact that effectiveness of banking sector's transformation processes implied radical changes in the sphere of workforce, which further required proper management where adequate management of employees played a significant role. An objective assessment of situation and development tendency of the banking sector reforms also require a study on status of human resources in the banking sector.

The main objective of this study was to, by analyzing and demonstrating complex relationships and correlations between organizational effectiveness of banks and human resource management practices, encourage promotion of this practice as well as to point out its strategic importance to the survival, growth and development of banks. There is intense pressure nowadays to show contribution of human resource management to organizational performances. Due to increasing competition in the global banking market, winning and retaining customers will become a key factor to effective operations, which in turn depends on employee competences within the organizations, since quality of service, as the most efficient means of winning and retaining clients, primarily depends on the quality of service provider. Therefore, to achieve the quality of banking services in order to win and retain clients, there are three important conditions: hiring of right people with the right knowledge, abilities and skills required for achieving effectiveness of banking services, having people motivated to invest their knowledge, skills and abilities in providing services, having their knowledge, skills and abilities constantly upgraded and replaced by new ones due to dynamics of business. Large investments in quality of human resource management practice are necessary for fulfilling of three above-mentioned conditions. In order to justify the investment, it is necessary to explain its importance for achieving effectiveness, i.e. to establish a clear correlation between HRM practices and business performance of organizations. In fact, if dimensions that are considered essential for effectiveness of an organization are not measured, they cannot be improved. To improve and promote a practice is possible only if a current state is known, i.e. current level of its contribution. It means that only organizations that have information about effectiveness of their employee management practices have the basis for its further development in order to achieve better business effectiveness. However, the bankruptcy case of one of the top banks in the 
Vemić Đurković J. et at.: A Comparative Analysis of Contribution of Human Resource...

study due to poor risk management as a result of influence of powerful political factors, corruption and conflict of interest, confirmed our observation mentioned at the beginning of the paper that human resources management is significant, but not the only decisive factor in achieving effectiveness.

\section{References}

Albert, M. (1990). HR Profit Power. Personnel, 67(2), 47-49.

Arthur, J.B. (1994). Effects of human resource systems on manufacturing performance and turnover. Academy of Management Journal, 27(3), 670-87. doi:10.2307/256705

Becker, B., \& Gerhart, B. (1996). The impact of human resource management on organizational performance: Progress and prospects. Academy of Management Journal, 39(4), 779-801.

Collins, C., Smith, K.G., \& Stevens, C.K. (2001). Knowledge-creation capability and performance in high technology firms. In Human Resource Practices. [online]. Retrieved from www.ilr.cornell.edu/cahrs

Delaney, J.T., \& Huselid, M.A. (1996). The impact of human resource management practices on perceptions of organizational performance. Academy of Management Journal, 39(4), 949-969.

Delery, J.E., \& Doty, D.H. (1996). Modes of Theorizing in Strategic Human Resource Management: Tests of Universalistic, Contingency, and Configurational Performance Predictions. Academy of Management Journal, 39(4), 802-835.

Huselid, M.A., \& Becker, B.E. (1997). The Impact of High Performance Work Systems, Implementation Effectiveness, and Alignment with Strategy on Shareholder Wealth. (p. 123). Retrieved from www.ilr.cornell.edu/cahrs

Ichniowski, C., Shaw, K., \& Prennushi, G. (1997). The effects of human resource management practices on productivity: A study of steel finishing lines. American Economic Review, 87(3), 291-313.

Kravetz, D. (1988). The Human Resources Revolution - Implementing Progressive Management Practices for Bottom-Line Success. San Francisco, CA: JosseyBass Publishers.

Terpstra, D.E., \& Rozell, E.J. (1993). The Relationship of Staffing Practices to Organizational Level Measures of Performance. Personnel Psychology, 46(1), 27-48.

Welbourne, T.M., \& Andrews, A.O. (1996). Predicting the performance of initial public offerings: should human resource management be in the equation. Academy of Management Journal, 39(4), 891-919.

Wright, P., McMahon, G., \& McWillams, A. (1994). Human and sustained competitive advantage: A resource-based perspective. International Journal of Human Resource Management, 5(2), 301-326.

Zubović, J., Jeločnik, M., \& Subić, J. (2011). Analiza HR indeksa u finansijskom sektoru Srbije. Industrija, 39(1), 227-242. 